Vol. 1, No. 1 | January - June 2018

\title{
Power Quality Analysis of Controlled Rectifiers and their Impact on Input Power System
}

\author{
Abdul Ghaffar ${ }^{1}$,Engr. Jahangir Badar Soomro ${ }^{1}$,Altaf Hussain ${ }^{1}$, Dr. Faheem A. \\ Chachar ${ }^{1}$
}

\begin{abstract}
:
This paper introduces the power quality analysis of AC-DC converter topologies and discusses their impact on input power system. Due to latest advancement in the technologies and power semiconductor devices, it is impossible to put barriers for the applications of power electronics topologies. These topologies are of different structure and causes harmonics when connected to the power system, these harmonics affects not only the power quality of the system network but also increase conductor overheating and core losses in motor applications. Due to their wide usage of rectifiers, it is necessary to observe its impact on the input power system, which includes THD (total harmonic distortion) and distortion in the input power factor etc. This research work focuses on the power quality analysis of the input power system due to AC-DC converters. In this paper input THD of single-pulse, two-pulse and six-pulse controlled rectifiers are examined using FFT analysis in MATLAB its effect on input power system are also observed.
\end{abstract}

\section{Introduction}

The AC-DC converter is by far the largest group of power switching circuits applied in industrial applications [1-3]. Usually rectifiers are developed using diodes and thyristors to provide uncontrolled and controlled DC power at the output with unidirectional and bidirectional power flow [4]. The drawback that comes with these rectifiers is that they cause non-linearity in the system which causes the harmonics to be injected in the system. These harmonics cause current distortion as well as poor power factor at the input side.

The difference between a linear and nonlinear load is that a linear load is a load which draws current from the supply which is proportional to the applied voltage, whereas a load is considered non-linear load when its impedance changes with the applied voltage, due to that change in impedance current drawn by the load is non-linear and that non-linear current carries harmonics with it. The power electronics converters also lie in the family of non-linear load.

"IEEE 519-1992 defines harmonics as a sinusoidal component of a periodic wave or quantity (e.g. voltage or current) having a frequency that is an integral multiple of the fundamental frequency" [5].

Harmonics causes many unwanted effects in the system network. The most saviour effect

${ }^{1}$ Dept. of Electrical Engineering, Sukkur IBA University, Sukkur, Pakistan

Corresponding Email: aghaffar.es14@iba-suk.edu.pk 
is the heating of equipment caused by iron losses and copper losses. A simple three phase nonlinear load is six-pulse rectifier and this type of load produces a significant amount of harmonics in the system network. Harmonics are not only generated by the non-linear loads but also the linear loads like rotating machines or transformers but their magnitude is quite low.

Increasing the number of pulses of rectifiers like six-pulse, twelve-pulse decreases the effect of harmonics by the formula

$\mathrm{h}=\mathrm{np} \pm 1$

where $\mathrm{n}$ is the number integer.

$\mathrm{p}$ is the number of pulses.

$\mathrm{h}$ is the harmonics order.

This paper comprises the comparative analysis of the harmonics effect of rectifier topologies (i.e. single-pulse, two-pulse, sixpulse and twelve-pulse) and their effect on input supply as well as on input power factor at different power factor using different loads.

\section{Methodology}

For performing the experimental study and analysis of Harmonics Generation Rectifiers the approach would be as designing of different topologies of rectifiers. For each configuration, the simulation would be done through MATLAB/Simulink. The simulated waveforms of current and voltage in case of different loads would be obtained by taking different firing angles and then correlate the effectiveness of different model and its configurations. Due to switching operations of AC-DC converters non-linearity is produced in the input current due to which harmonics are generated [6] which not only disturb the performance of converters but also quality of input power system is badly affected. The power quality factor would be observed by the Fluke Power Quality Analyzer that can monetize the cost of energy waste due to poor quality.

The implementation of different rectifiers circuits i.e. single pulse, two pulse, six pulse and twelve pulse would be done on simulation on MATLAB/Simulink using different techniques over different loads.

\section{Single Phase Half Wave Rectifier}

Power Converters are used whenever there is mismatch between power supply available and load requirement. The Thyristor can be triggered at any angle $\alpha$ in positive half cycle as well as in negative half cycle so that the output voltage can be controlled. The thyristor acts as an open during the negative half cycle [7].

\subsection{Single Phase Half Wave Controlled Rectifier with $\mathbf{R}$ Load}

Fig. 1. shows half wave controlled rectifier with resistive load. This topology is also known as 1-pulse rectifier.

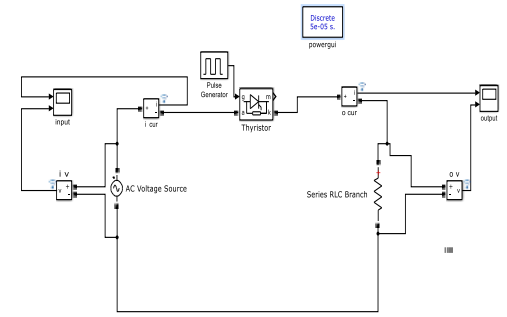

Fig. 1. Half Wave Controlled Rectifier with R load.
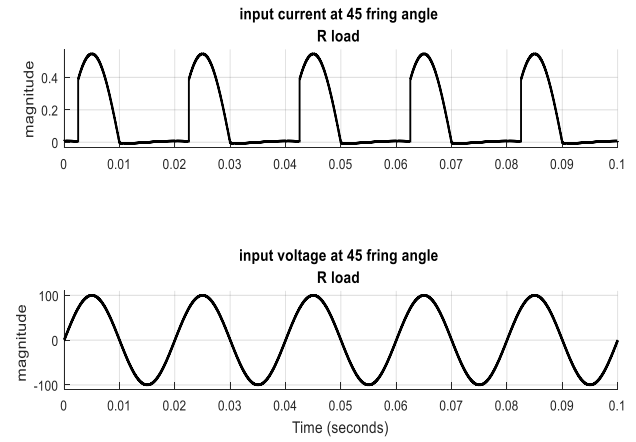

Fig. 2. Input Current and Voltage with $\mathrm{R}$ load at firing angle of $45^{\circ}$.

Input voltage and current waveform at firing angle of $45^{\circ}$ is shown in Fig. 2. Input current is no more a pure sinusoidal and Fig. 3 shows input current harmonics at firing angle of $45^{\circ}$. 


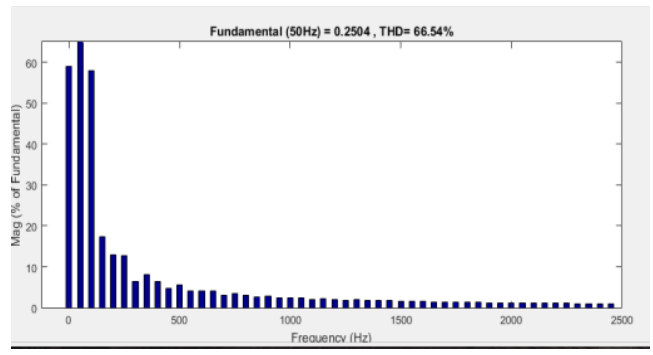

Fig. 3. Input Current THD with $\mathrm{R}$ load at firing angle of $45^{\circ}$.

Output current and voltage with resistive load is shown in Fig. 4. It can be seen from waveform that output is not pure DC and it contains AC components along with DC components.
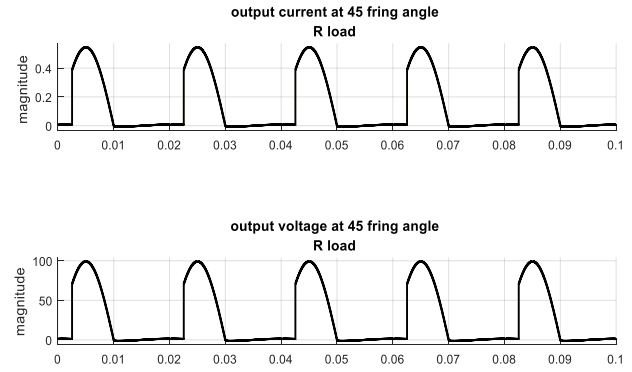

Fig. 4. Output Current and Voltage with R load at firing angle of $45^{\circ}$.

TABLE I. input, output, voltage thd, current thd and power factor with $r$ load at different firing angles.

\begin{tabular}{|c|c|c|c|c|}
\hline $\begin{array}{c}\text { Firin } \\
\mathrm{g} \\
\text { Angl } \\
\mathrm{e}\end{array}$ & $\begin{array}{c}\text { Input } \\
\text { Curren } \\
\mathrm{t} \\
\text { THD } \\
\%\end{array}$ & $\begin{array}{c}\text { Output } \\
\text { Curren } \\
t \\
\text { THD } \\
\%\end{array}$ & $\begin{array}{c}\text { Output } \\
\text { Voltag } \\
\text { e } \\
\text { THD } \\
\%\end{array}$ & $\begin{array}{c}\text { Input } \\
\text { Powe } \\
\text { r } \\
\text { facto } \\
\text { r }\end{array}$ \\
\hline $30^{\circ}$ & 55.38 & 55.38 & 55.38 & 0.69 \\
\hline $45^{\circ}$ & 66.54 & 66.54 & 66.54 & 0.67 \\
\hline $60^{\circ}$ & 80.36 & 80.36 & 80.36 & 0.63 \\
\hline $90^{\circ}$ & 115.24 & 115.24 & 115.24 & 0.50 \\
\hline
\end{tabular}

It can be seen from table that harmonics generated are increased by increasing firing angle and current and voltage harmonics are same due to resistive load. Also, Input power factor decreases by increasing firing angle as shown in Fig. 5.

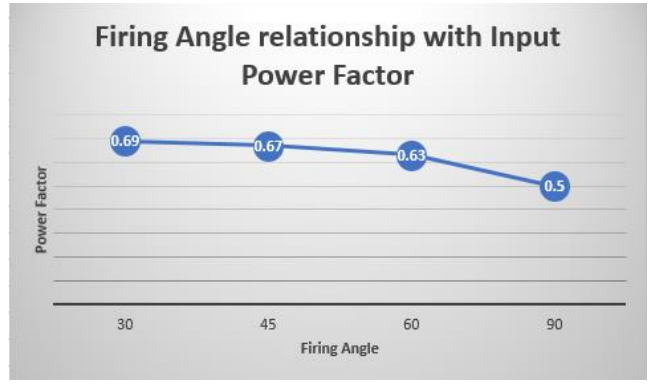

Fig. 5. Relationship of Firing angle and Input Power Factor.

\subsection{Single Phase Half Wave Controlled Rectifier with RL Load}

Input current and voltage with resistiveinductive load is shown in Fig.6.
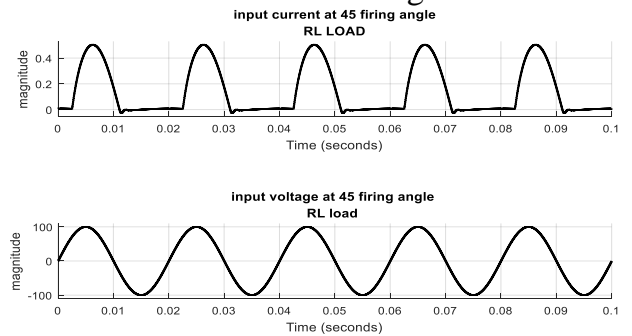

Fig. 6. Input Current and Voltage with RL load.

It can be seen that keeping all parameters same, current harmonics in resistive-inductive load is reduced than resistive load as shown in Fig. 7. Inductor works as a filter for current harmonics and therefore current waveform becomes smoother.

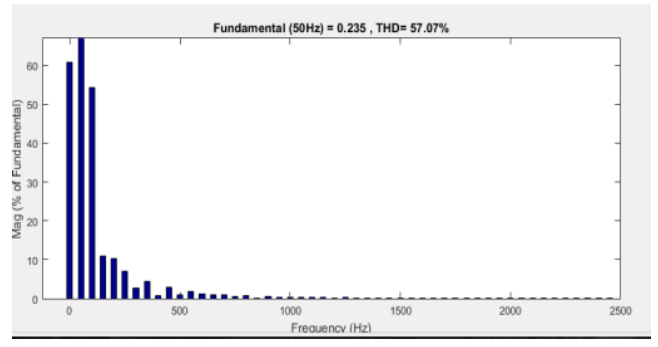

Fig. 7. Input Current THD with RL load at firing angle of $45^{\circ}$. 
Output current and voltage with resistiveinductive load is shown in Fig. 8. Voltage and current waveform are different due to resistive-inductive load.
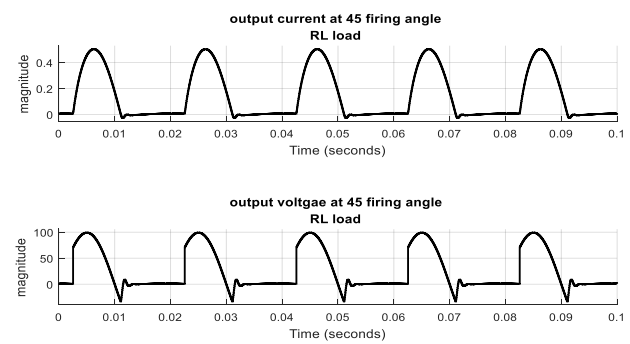

Fig. 8. Output Current and Voltage with RL load.

TABLE II. Input, Output, Voltage THD, Current THD and Power Factor with R Load at different Firing Angles.

\begin{tabular}{|c|c|c|c|c|}
\hline $\begin{array}{c}\text { Firin } \\
\mathrm{g} \\
\text { Angl } \\
\mathrm{e}\end{array}$ & $\begin{array}{c}\text { Input } \\
\text { Curren } \\
\mathrm{t}\end{array}$ & $\begin{array}{c}\text { Output } \\
\text { Curren } \\
\mathrm{t}\end{array}$ & $\begin{array}{c}\text { Output } \\
\text { Voltag } \\
\mathrm{e}\end{array}$ & $\begin{array}{c}\text { Input } \\
\text { Powe } \\
\%\end{array}$ \\
$\begin{array}{c}\mathrm{THD} \\
\mathrm{r}\end{array}$ & $\begin{array}{c}\text { facto } \\
\mathrm{r}\end{array}$ \\
\hline $30^{\circ}$ & 48.9 & 48.9 & 60.97 & 0.65 \\
\hline $45^{\circ}$ & 57.07 & 57.07 & 72.39 & 0.62 \\
\hline $60^{\circ}$ & 67.56 & 67.56 & 87.43 & 0.57 \\
\hline $90^{\circ}$ & 93.73 & 93.73 & 127.5 & 0.42 \\
\hline
\end{tabular}

In the above table it can be seen that the THD at the input side is increasing with the increase in the firing angle, also due to resistive-inductive nature of the load, the current ripples are filtered as an inductor opposes the change in current and due to this the current harmonics at the output is less than the voltage harmonics. It is observed that input power factor decreases with increase in firing angle as shown in Fig. 9.

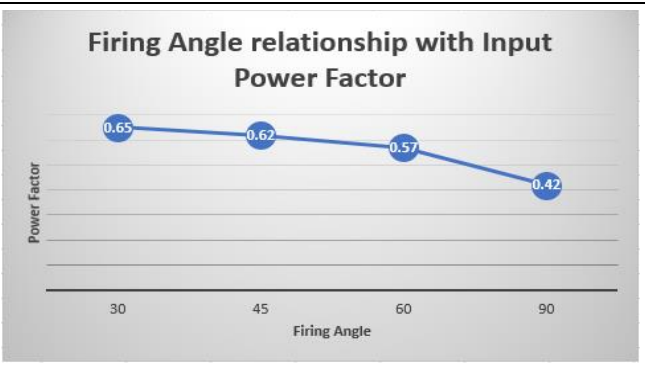

Fig. 9. Relationship of Firing angle and Input Power Factor.

\section{Single Phase Full Wave Controlled Rectifier}

A full-wave controlled rectifier converts both the positive as well as negative half cycle of input waveform and converts both polarities of the input waveform to pulsating DC. The desired value at the output can be achieved by varying the firing angle $\alpha$ of the thyristor [8].

\subsection{Single Phase Full Wave Controlled Rectifier with R Load}

Fig. 10. shows the single phase full wave controlled rectifier with resistive load. This topology is also known as 2-pulse rectifier.

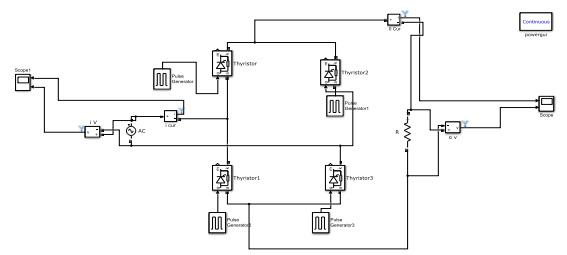

Fig. 10. Full Wave Controlled Rectifier with $\mathrm{R}$ load.
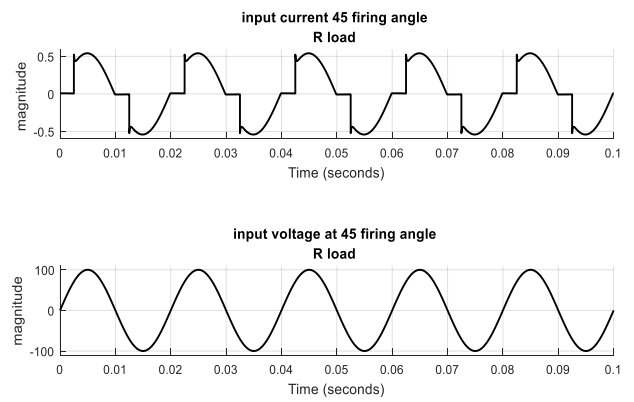

Fig. 11. Input Current and Voltage with R load. 
Abdul Ghaffar (et al.), Power Quality Analysis of Controlled Rectifiers and their Impact on Input Power System. (pp. $57-65)$

Input voltage and current waveform at firing angle of $45^{\circ}$ is shown in Fig. 11. Input current is distorted sinusoidal and Fig. 12 shows input current harmonics at firing angle of $45^{\circ}$.

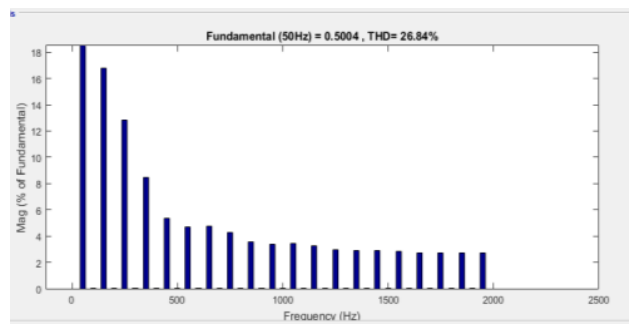

Fig. 12. Input Current THD with $\mathrm{R}$ load at firing angle of $45^{\circ}$.

Output current and voltage with resistive load is shown in Fig. 13. It can be seen from waveform that output is still not a pure dc and it contains ac components along with dc components but it has less ripple factor as compared to single phase half wave controlled rectifier.
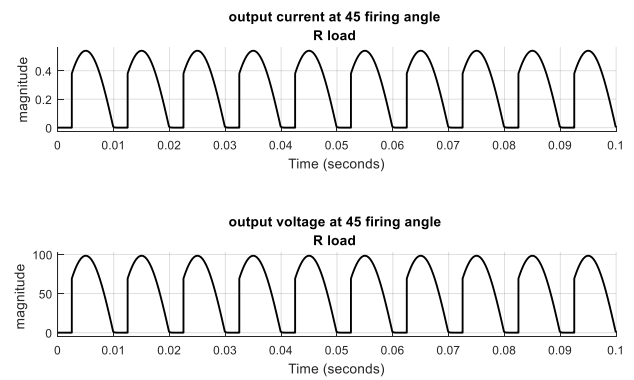

Fig. 13. Output Current and Voltage with $R$ load.

It can be seen form table that harmonics generated are increased by increasing firing angle and current and voltage harmonics are same due to resistive load. Also Input power factor decreases by increasing firing angle as shown in Fig. 14.
TABLE III. Input, Output, Voltage THD,

Current THD and Power Factor with R Load at different Firing Angles.

\begin{tabular}{|c|c|c|c|c|}
\hline $\begin{array}{c}\text { Firing } \\
\text { Angle }\end{array}$ & $\begin{array}{c}\text { Input } \\
\text { Current } \\
\text { THD \% }\end{array}$ & $\begin{array}{c}\text { Output } \\
\text { Current } \\
\text { THD \% }\end{array}$ & $\begin{array}{c}\text { Output } \\
\text { Voltage } \\
\text { THD \% }\end{array}$ & $\begin{array}{c}\text { Input } \\
\text { Power } \\
\text { factor }\end{array}$ \\
\hline $30^{\circ}$ & 16.32 & 30.57 & 30.57 & 0.98 \\
\hline $45^{\circ}$ & 26.8 & 33.47 & 33.47 & 0.95 \\
\hline $60^{\circ}$ & 40.4 & 37.1 & 37.1 & 0.89 \\
\hline $90^{\circ}$ & 70.39 & 57.5 & 57.5 & 0.70 \\
\hline
\end{tabular}

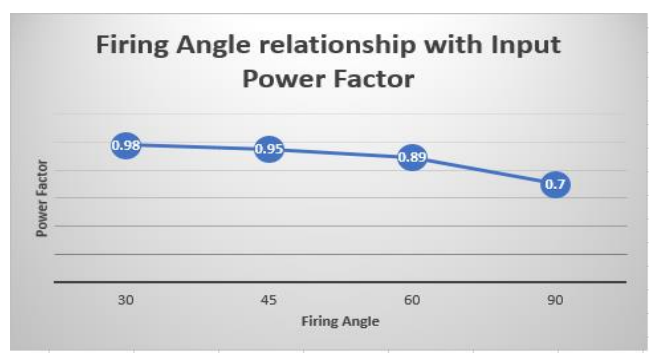

Fig. 14. Relationship of Firing angle and Input Power Factor.

\subsection{Single Phase Full Wave Controlled Rectifier with RL Load}

Input current and voltage with resistiveinductive load is shown in Fig. 15.
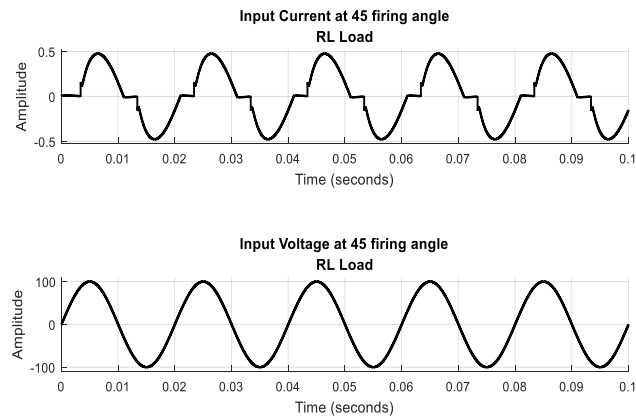

Fig. 15. Input Current and Voltage with RL load.

It can be seen that keeping all parameters same, current harmonics in resistive-inductive load is reduced than resistive load as shown in Fig. 16. 


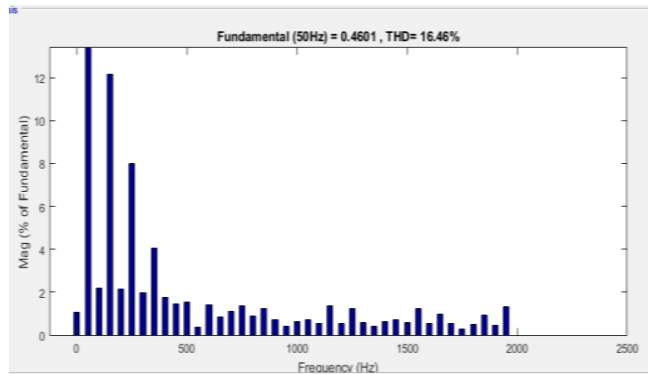

Fig. 16. Input Current THD with RL load at firing angle of $45^{\circ}$.

Output current and voltage with resistiveinductive load is shown in Fig. 17. Voltage and current waveform are different due to resistive-inductive load.
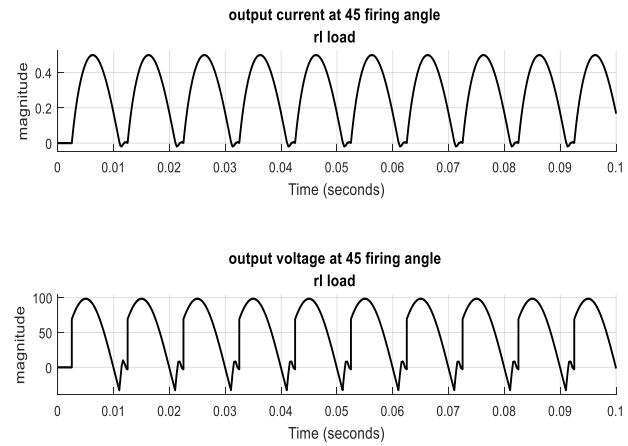

Fig. 17. Output Current and Voltage with RL load.

Table IV. Input, Output, Voltage THD, Current THD and Power Factor with RL Load at different Firing Angles.

\begin{tabular}{|c|c|c|c|c|}
\hline $\begin{array}{c}\text { Firin } \\
\mathrm{g} \\
\text { Angl } \\
\mathrm{e}\end{array}$ & $\begin{array}{c}\text { Input } \\
\text { Curren } \\
\mathrm{t} \\
\text { THD } \\
\%\end{array}$ & $\begin{array}{c}\text { Output } \\
\text { Curren } \\
\mathrm{t} \\
\text { THD } \\
\%\end{array}$ & $\begin{array}{c}\text { Output } \\
\text { Voltag } \\
\text { e } \\
\text { THD } \\
\%\end{array}$ & $\begin{array}{l}\text { Input } \\
\text { Powe } \\
r \\
\text { facto } \\
r\end{array}$ \\
\hline $30^{\circ}$ & 9.49 & 26.85 & 31.16 & 0.93 \\
\hline $45^{\circ}$ & 16.4 & 21.51 & 33.47 & 0.89 \\
\hline $60^{\circ}$ & 25.25 & 19.67 & 37.14 & 0.82 \\
\hline $90^{\circ}$ & 49.39 & 37.22 & 56.65 & 0.62 \\
\hline
\end{tabular}

It is observed that input power factor decreases with increase in firing angle as shown in Fig. 18. Harmonics increases due to increase in firing angle, thereby input power factor decreases.

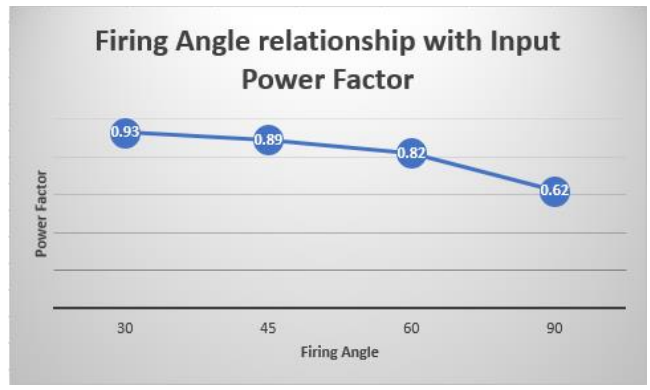

Fig. 18. Relationship of Firing angle and Input Power Factor.

\section{Three Phase Full Wave Controlled Rectifier}

In industrial applications where three phase AC voltages are available it Is preferred to use three phase rectifiers, as it gives us multiple benefits like high power handling, low ripple factor which reduces the filter size as well as low distortion at the input [9].

Application of higher pulse rectifiers are found at various points like for pipeline pumps in petrochemical industry, for steel rolling mills in metal industry, for pumps in water pumping stations, for fans in cement industry, for traction in locomotive industry etc [10].

\subsection{Three Phase Full Wave Controlled Rectifier with R Load}

Fig. 19. shows three phase full wave controlled rectifier with resistive load. This topology is also known as 6-pulse rectifier.

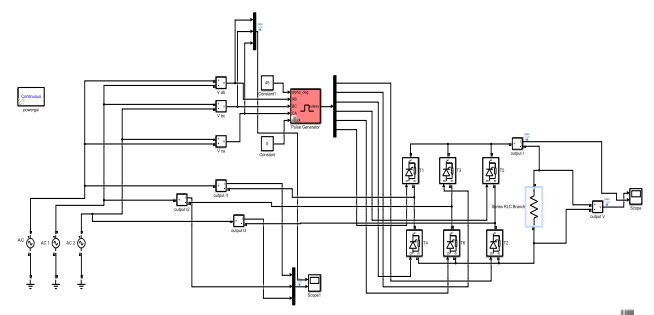

Fig. 19. Full Wave Controlled Rectifier with $\mathrm{R}$ load. 

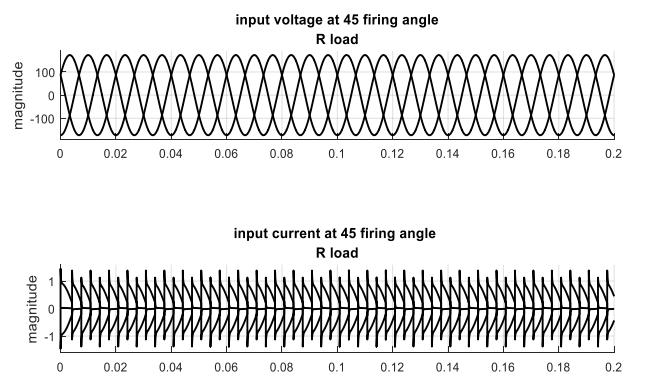

Fig. 20. Input Current and Voltage with $R$ load.

Input voltage and current waveform at firing angle of $45^{\circ}$ is shown in Fig. 20. Input current is no more a pure sinusoidal and Fig. 21. shows input current harmonics at firing angle of $45^{\circ}$.

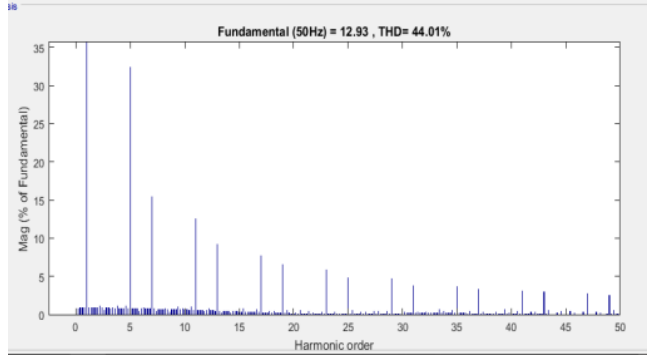

Fig. 21. Input Current THD with $\mathrm{R}$ load at firing angle of 45 .

Output current and voltage with resistive load is shown in Fig. 22. Six pulse rectifier has less ripple factor and thus requires smaller filter size.
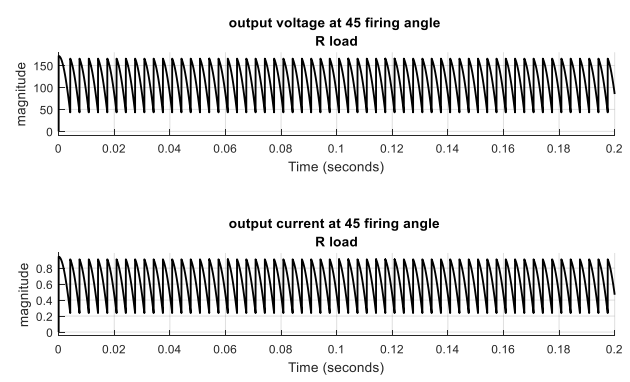

Fig. 22. Output Current and Voltage with $R$ load.
TABLE V. Input, Output, Voltage THD, Current THD and Power Factor with R Load at different Firing Angles.

\begin{tabular}{|c|c|c|c|c|}
\hline $\begin{array}{c}\text { Firing } \\
\text { Angle }\end{array}$ & $\begin{array}{c}\text { Input } \\
\text { Current } \\
\text { THD \% }\end{array}$ & $\begin{array}{c}\text { Output } \\
\text { Current } \\
\text { THD \% }\end{array}$ & $\begin{array}{c}\text { Output } \\
\text { Voltage } \\
\text { THD \% }\end{array}$ & $\begin{array}{c}\text { Input } \\
\text { Power } \\
\text { factor }\end{array}$ \\
\hline $30^{\circ}$ & 35.55 & 75.62 & 75.62 & 0.51 \\
\hline $45^{\circ}$ & 44.01 & 77 & 77 & 0.32 \\
\hline $60^{\circ}$ & 62.09 & 78 & 78 & 0.13 \\
\hline
\end{tabular}

It can be seen from the results that power quality of three phase rectifiers is better than single phase, also Input power factor decreases by increasing firing angle as shown in Fig. 23.

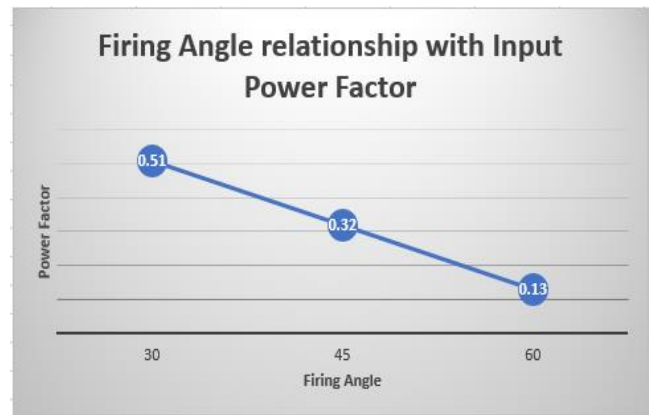

Fig. 23. Relationship of Firing angle and Input Power Factor.

\subsection{Three Phase Full Wave Controlled Rectifier with RL Load}

Input current and voltage with resistiveinductive load is shown in Fig. 24.

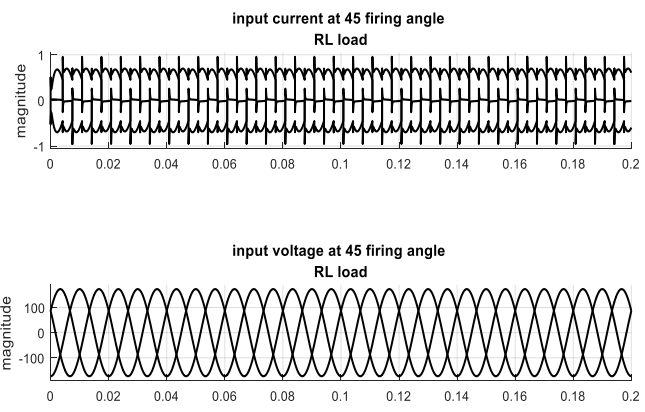

Fig. 24. Input Current and Voltage with RL load. 
It can be seen that keeping all parameters same, current harmonics in resistive-inductive load is reduced than resistive load as shown in Fig. 25.

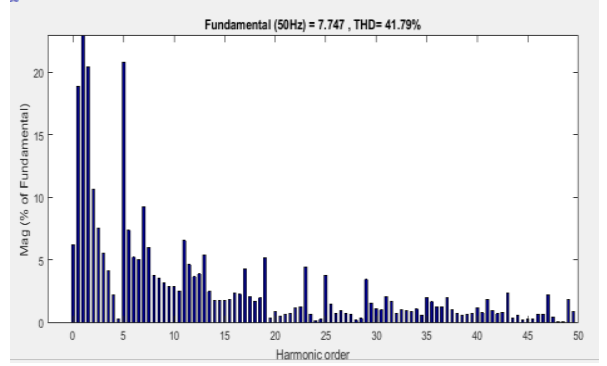

Fig. 25. Input Current and Voltage with RL load.

Output current and voltage with resistiveinductive load is shown in Fig. 26. Voltage and current waveform are different due to resistive-inductive load.

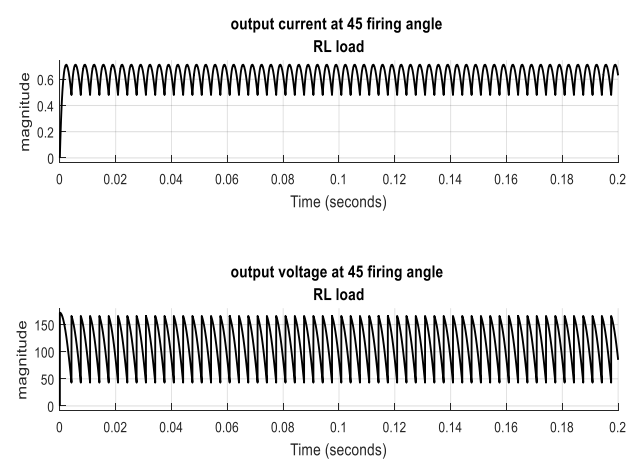

Fig. 26. Output Current and Voltage with RL load.

TABLE VI. Input, Output, Voltage THD, Current THD and Power Factor with RL Load at different Firing Angles.

\begin{tabular}{|c|c|c|c|c|}
\hline $\begin{array}{c}\text { Firing } \\
\text { Angle }\end{array}$ & $\begin{array}{c}\text { Input } \\
\text { Current } \\
\text { THD \% }\end{array}$ & $\begin{array}{c}\text { Output } \\
\text { Current } \\
\text { THD \% }\end{array}$ & $\begin{array}{c}\text { Output } \\
\text { Voltage } \\
\text { THD \% }\end{array}$ & $\begin{array}{c}\text { Inp } \\
\text { ut } \\
\text { Po } \\
\text { wer } \\
\text { fact } \\
\text { or }\end{array}$ \\
\hline $30^{\circ}$ & 38.65 & 56.40 & 75.64 & $\begin{array}{c}0.4 \\
7\end{array}$ \\
\hline $45^{\circ}$ & 41.79 & 58 & 77.35 & $\begin{array}{c}0.2 \\
4\end{array}$ \\
\hline
\end{tabular}

The results of six pulse rectifier for resistive-inductive load are shown in above table. The relationship of input power factor with firing angle is also demonstrate in Fig. 27.

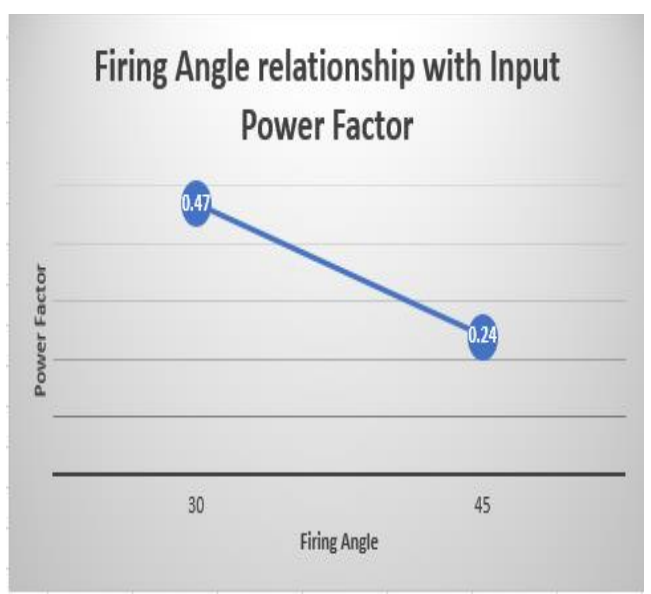

Fig. 27. Relationship of Firing angle and Input Power Factor.

\section{Conclusion}

From the comparison of above results and relationship of higher pulses with THD it can be concluded that as we move towards the higher pulses, the THD at the input is decreased or simply the input supply distortion decreases with the increase in the number of pulses. Another advantage is that filter size will reduce and filter losses will be minimized as we move towards higher pulses rectifiers. Thus, ripple factor at the output of the higher pulse rectifiers (i.e. 12-pulse, 18-pulse and 24pulse) will be very less. The power factor is also less disturbed which also saves our economy as the disturbed power factor would increase the copper losses in the system as well as it would increase the stress on the switching devices, insulators and heating effect. In HVDC Transmission System higher pulses rectifiers are preferred because of their huge advantages like economy, minimum losses and reliability. 


\section{REFERENCES}

[1] B. K. Bose, "Recent Advances in Power Electronics," IEEE Transactions on Power Electronics, vol. 7, no. 1, pp. 2 - 16, 1992.

[2] T. Tanaka, S. Fujikawa, and S. Funabiki, "A New Method of Damping Harmonic Resonance at the DC Link in Large-Capacity RectifierInverter Systems Using a Novel Regenerating Scheme", IEEE Transaction on Industry Applications, vol. 38, no. 4, Page(s):1131 - 1138, July/August 2002.

[3] O. Garcia, M. D. Martinez-Avial, J.A. Cobos, J. Uceda, J. Gonzalez, and J. A. Navas, "Harmonic Reducer Converter," IEEE Transactions on Industrial Electronics, vol 50, no. 2, pp. 322 - 327, April 2003.

[4] Baharom, R., Hashim, N. and Hamzah, M.K., 2009, November. Implementation of controlled rectifier with power factor correction using single-phase matrix converter. In Power Electronics and Drive Systems, 2009. PEDS 2009. International Conference on (pp. 1020-1025), IEEE.

[5] F II, I., 1993. IEEE recommended practices and requirements for harmonic control in electrical power systems. New York, NY, USA.

[6] Mahar, M.A., Larik, A.S., and Shah, A.A., "Impacts on power factor of ac voltage controllers under nonsinusoidal conditions," Mehran University Research Journal of Engineering and Technology, vol. 31, no. 2, pp.297-300, 2012.

[7] Solanki, A., "Simulation \& Performance Parameters Analysis of Single-Phase Full Wave Controlled Converter using PSIM," International Journal of Engineering Research and General Science, vol. 2, no. 3, pp.410414, 2014.

[8] Mahobia, S.K. and Kumrey, G.R., "Study and Performance of SinglePhase Rectifiers with Various Type of Parameter," International Journal in Engineering Technologies and Management Research, vol. 3, no. 1, pp. 9-14, 2016.

[9] Mohan, N. and Mohan, T.M., 1995. Power electronics (Vol. 3). New York: John wiley \& sons.

[10] Pyakuryal, S. K., "Control of harmonics in 6-pulse rectifiers (Doctoral dissertation, University of Denver)," 2013. 